Background: Airway smooth muscle (ASM) is considered to be a target for mediators released during airway inflammation.

Aims: To investigate the expression of c-fos, a constituent of the transcription factor activator protein-1, in human ASM cells. In addition, to measure the release of interleukin (IL)-6 into the conditioned medium of stimulated ASM cells, as well as DNA biosynthesis and changes in cell number.

Methods: Serum-deprived human ASM cells in the $G_{0} / G_{1}$ phase were stimulated with the pro-inflammatory cytokines; tumour necrosis factor- $\alpha, \mathrm{IL}-1 \beta$, IL-5 and IL-6. The expression of mRNA encoding the proto-oncogene c-fos was measured by Northern blot analysis. Cell proliferation was assessed by $\left\{{ }^{3} \mathrm{H}\right\}$-thymidine incorporation assays and cell counting, and IL-6 levels in cell-conditioned medium were measured by enzyme-linked immunosorbent assay.

Results: All of the cytokines investigated induced a rapid (within $1 \mathrm{~h}$ ) and transient increase in the expression of mRNA encoding c-fos, followed by the expression and enhanced release of IL-6. Cell proliferation remained unchanged in cytokine-stimulated cells.

Conclusions: Cytokine-induced c-fos expression in human ASM cells could be described as a marker of cell 'activation'. The possible association of these results with airway inflammation, through secondary intracellular mechanisms such as cytokine production, is discussed.

Key words: Airway smooth muscle, Cytokine, c-fos, IL-6, TNF- $\alpha$, IL-1 $\beta$, IL-5

\section{Pro-inflammatory cytokines induce c-fos expression followed by IL-6 release in human airway smooth muscle cells}

Sue McKay ${ }^{1}$, Mechteld M. Grootte Bromhaar ${ }^{1}$, Johan C. de Jongste ${ }^{2}$, Henk C. Hoogsteden ${ }^{3}$, Pramod R. Saxena ${ }^{1}$ and Hari S. Sharma ${ }^{1, C A}$

${ }^{1}$ Department of Pharmacology, Erasmus University Medical Center (EMCR), Dr. Molewaterplein 50, 3015 GE Rotterdam, The Netherlands; ${ }^{2}$ Department of Paediatrics-Respiratory Medicine, Sophia Children's Hospital; ${ }^{3}$ Department of Pulmonary-Medicine, Erasmus University Medical Centre Rotterdam, The Netherlands

\footnotetext{
${ }^{\mathrm{CA}}$ Corresponding Author

Tel: (+31) 104087963

Fax: (+31) 104089458

E-mail: sharma@farma.fgg.eur.nl
}

\section{Introduction}

Asthma is a chronic disease of the airways characterised by reversible airway obstruction, airway hyper-responsiveness and airway wall inflammation. Important pathological features of asthmatic airways include inflammatory cell infiltration, epithelial shedding, basement membrane thickening and increased mass of airway smooth muscle (ASM). Both hyperplasia (an increase in cell number) and hypertrophy (an increase in cell size) of ASM cells contribute to the increased smooth muscle content of the airway wall. ${ }^{1-3}$ The release of mediators from the infiltrating inflammatory cells has been proposed to contribute to changes in airway structure. The resulting changes form the basis for airway wall remodelling, a phenomenon believed to have profound consequences on airway function. Human ASM cells in culture provide a useful model for investigating physiological responses, and studies of human ASM cell responses to mediators of asthma are important for understanding the mechanisms involved in airway inflammation and remodelling.
Bronchoalveolar lavage fluid and serum from symptomatic asthma patients contains significantly increased levels of pro-inflammatory cytokines, growth factors and other inflammatory mediators, suggesting that these mediators may also be in the vicinity of the airway mucosa..$^{4-11}$ Moreover, pro-inflammatory cytokines such as tumour necrosis factor- $\alpha$ (TNF- $\alpha$ ), interleukin (IL)- $1 \beta$ and IL- 6 have been reported to stimulate DNA synthesis in cultured ASM cells derived from different species. ${ }^{12-14}$ IL-6 has pro-inflammatory effects that may be relevant to airway wall inflammation, including mucus hypersecretion, the terminal differentiation of $\mathrm{B}$ cells into antibody producing cells, upregulation of IL-4-dependent immunoglobulin $(\mathrm{Ig}) \mathrm{E}$ production, and differentiation of immature mast cells. ${ }^{15-18}$ Possible anti-inflammatory properties of IL- 6 include the inhibition of macrophage cytokine production, stimulation of the production of anti-inflammatory molecules such as IL-1 receptor antagonist and soluble TNF receptor $\mathrm{p} 55$, and reduced airway responsiveness. ${ }^{19-24}$ 
The nuclear proto-oncogene c-fos is a member of the leucine zipper family and it heterodimerises with c-jun to constitute the AP-1 transcription factor. ${ }^{25}$ Induction of c-fos, and subsequent cell proliferation and/or differentiation, has previously suggested that c-fos can be considered a proliferation marker. ${ }^{25,26}$ The purpose of the present study was to investigate the effects of a range of cytokines (TNF- $\alpha$, IL-1 $\beta$, IL- 5 and IL-6) on the expression of the immediate early response gene, c-fos, as well as the release of the pleiotropic cytokine IL-6 in cultured human ASM cells. Our results demonstrate that all of the cytokines investigated induced a rapid and transient expression of mRNA encoding c-fos. Moreover, they induced the release of IL- 6 protein into the conditioned medium. However, none of the cytokines stimulated DNA biosynthesis or ASM cell mitogenesis. These results suggest that it may be preferable to describe c-fos as a marker of 'activation' in ASM cells - leading to the expression of cytokines, such as IL-6, rather than as a marker of proliferation.

\section{Materials and methods}

\section{Materials}

The following solutions and reagents were obtained from Life Technologies BV (Breda, The Netherlands): sodium pyruvate, non-essential amino acid mixture, gentamicin, penicillin/streptomycin, amphotericin B, Dulbecco's modified Eagle's medium (DMEM), and $0.5 \%$ trypsin $/ 0.02 \%$ ethylenediamine tetraacetic acid (EDTA). Insulin, transferrin and ascorbate, IL-1 $\beta$ and IL-5 were purchased from Sigma BV (Zwijndrecht, The Netherlands). We procured foetal bovine serum (FBS) from Bio-Whitaker BV (Verviers, Belgium), TNF- $\alpha$ from Knoll AG (Ludwigshaven, Germany), metbyl$\left[{ }^{3} \mathrm{H}\right]$-thymidine from Amersham Nederland BV ('s-Hertogenbosch, The Netherlands) and recombinant human IL-6 from Promega (Leiden, The Netherlands). Human specific antibodies for the IL-6 enzymelinked immunosorbent assay (ELISA assay) were procured from Medgenix (Breda, The Netherlands).

\section{Human ASM cell culture}

Human bronchial smooth muscle cells were isolated as described previously. ${ }^{27,28}$ Briefly, bronchial smooth muscle was dissected from a fresh macroscopically normal lobar or main bronchus obtained immediately following surgery of patients with lung carcinoma. The medical ethical and research committee of Erasmus University Medical Center approved this study (MEC 150.321/1996/45). After removal of the epithelium, pieces of smooth muscle were dissected free of adherent connective and parenchymal tissue under aseptic conditions. Smooth muscle fragments were incubated in HBSS containing bovine serum albumin (fraction $\mathrm{V}, 10 \mathrm{mg} / \mathrm{ml}$ ), collagenase (type XI, $1 \mathrm{mg} / \mathrm{ml}$ ) and elastase (type $\mathrm{IV}, 3.3 \mathrm{U} / \mathrm{ml}$ ) at $37^{\circ} \mathrm{C}$ in a humidified incubator (ASSAB, model T154; Clean Air Techniek BV, Woerden, The Netherlands) containing $5 \% \mathrm{CO}_{2}$ in air. After enzymatic digestion, the cell suspension was centrifuged and the pellet was washed in DMEM containing $10 \%(\mathrm{v} / \mathrm{v})$ FBS supplemented with sodium pyruvate $(1 \mathrm{mM})$, non-essential amino acid mixture (1:100), gentamicin $(45 \mu \mathrm{g} / \mathrm{ml})$, penicillin $(100 \mathrm{U} / \mathrm{ml})$, streptomycin $(100 \mu \mathrm{g} / \mathrm{ml})$ and amphotericin B $(1.5 \mu \mathrm{g} / \mathrm{ml})$. Cells were subsequently seeded in a $35 \mathrm{~mm}$ dish and maintained in culture by replacing the medium every $72 \mathrm{~h}$. After 10-14 days in culture, ASM cells grew to confluence and were then removed from the plastic base of each dish using $0.5 \%$ trypsin/0.02\% EDTA, and sub-cultured into $25 \mathrm{~cm}^{2}$ tissue culture flasks. At confluence, cells were further passaged using trypsin/EDTA solution into $75 \mathrm{~cm}^{2}$ tissue culture flasks. Confluent cells in the fourth to sixth passages were used for experiments.

\section{Stimulation of human ASM cells}

The ASM cell growth was synchronised prior to treatment by washing the cell monolayers twice in phosphate-buffered saline (PBS) (140 mM NaCl, $2.6 \mathrm{mM} \mathrm{KCl}, \quad 1.4 \mathrm{mM} \quad \mathrm{KH}_{2} \mathrm{PO}_{4}, \quad 8.1 \mathrm{mM} \quad \mathrm{Na}{ }_{2} \mathrm{H}-$ $\left.\mathrm{PO}_{4} \cdot 2 \mathrm{H}_{2} \mathrm{O} ; \mathrm{pH} 7.4\right)$ and then replacing the medium with serum-free DMEM supplemented with $1 \mu \mathrm{M}$ insulin, $5 \mu \mathrm{g} / \mathrm{ml}$ transferrin and $100 \mu \mathrm{M}$ ascorbate for $72 \mathrm{~h}$. Using flow cytometric analysis of human ASM cells, we have found that $72 \mathrm{~h}$ of serum deprivation resulted in approximately 85-90\% of the cells remaining in the $G_{0} / G_{1}$ phase. Growth-arrested cell monolayers were treated with either TNF- $\alpha(10 \mathrm{ng} / \mathrm{ml})$, IL$1 \beta(0.5 \mathrm{ng} / \mathrm{ml})$, IL-5 $(2 \mathrm{ng} / \mathrm{ml})$ or IL- $6(5 \mathrm{ng} / \mathrm{ml})$ in fresh FBS-free DMEM in a time-dependent manner. Cellconditioned medium was collected and stored at $-20^{\circ} \mathrm{C}$ until assayed for IL- 6 levels by ELISA. Stimulation of human ASM cells with cytokines can induce the release of prostaglandins, which may then inhibit the proliferation of ASM cells. ${ }^{29}$ Therefore, we also examined the effects of the aforementioned cytokines on human ASM cell proliferation in the presence of indomethacin $(1 \mu \mathrm{M})$, which is a non-specific cyclooxygenase inhibitor.

\section{Isolation of total cellular RNA and Northern blot analysis}

Treated and untreated human ASM cells were washed in PBS and directly lysed in guanidinium thiocyanate buffer. The lysate was repeatedly passed through a 23-gauge needle to shear the genomic DNA. Total cellular RNA was isolated using the method as described earlier. ${ }^{27}$ The RNA concentration was estimated by optical density measurements and a DNA/ protein ratio of $\geq 1.8$ was accepted. Samples of total 
A

$\begin{array}{lllllll}\text { C } & 15 & 30 & 45 & 60 & 120 & 240\end{array}$

$\begin{array}{lllllll}C & 15 & 30 & 45 & 60 & 120 & 240\end{array}$
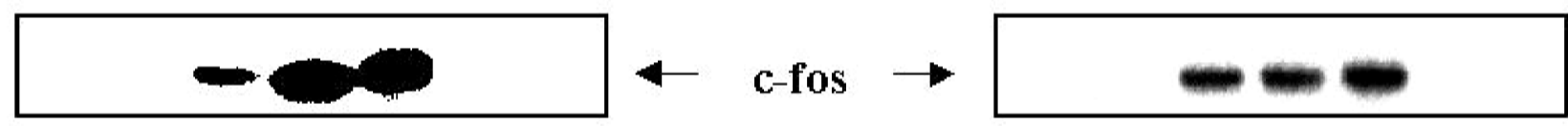

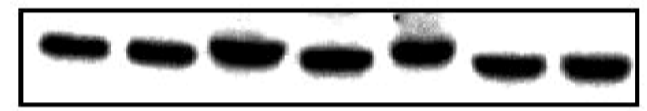

IL-1 $\beta$

B

$\begin{array}{lllllll}\text { C } & 15 & 30 & 45 & 60 & 120 & 240\end{array}$
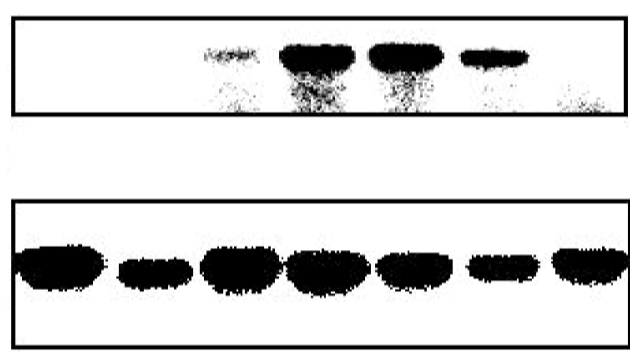

IL-5

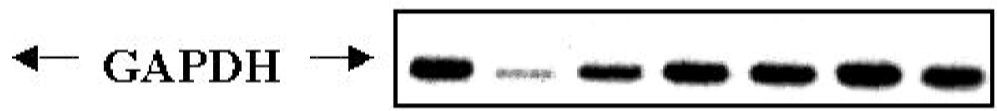

IL-6

D

$\begin{array}{lllllll}\mathrm{C} & 15 & 30 & 45 & 60 & 120 & 240\end{array}$

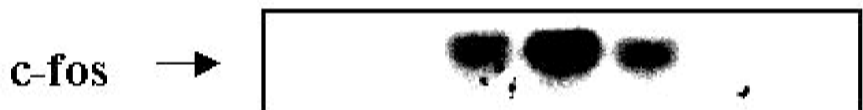

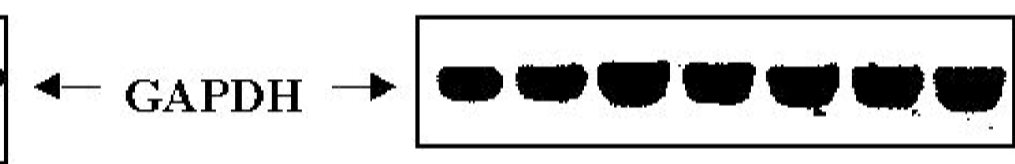

TNF- $\alpha$

FIG. 1. Representative Northern blots of c-fos expression in human airway smooth muscle (ASM) cells treated with: (A) IL-1 $\beta$ $(0.5 \mathrm{ng} / \mathrm{ml})$, (B) IL-5 $(2 \mathrm{ng} / \mathrm{ml})$, (C) IL-6 ( $5 \mathrm{ng} / \mathrm{ml})$, or (D) TNF- $\alpha(10 \mathrm{ng} / \mathrm{ml})$. Total RNA from control C (cultured in serum-free DMEM) and treated cells was subjected to Northern hybridisation with a radiolabelled c-fos cDNA probe. Rehybridisation of each filter with a GAPDH cDNA probe was performed for reference purposes. These Northern blots are representative of blots from three independent experiments.

RNA $(10 \mu \mathrm{g})$ were denatured at $65^{\circ} \mathrm{C}$ in a formaldehyde-containing loading buffer and size fractionated on a $1 \%$ agarose gel containing $2.2 \mathrm{M}$ formaldehyde. Ethidium bromide stained gels were photographed and RNA was transferred onto hybond-N membrane (Amersham Nederland BV) by the alkaline downward capillary transfer method also described previously. ${ }^{27}$ The filters were air-dried and ultraviolet cross-linked in a gene linker (Biorad Laboratories B.V., Veenendaal, The Netherlands). Blots were hybridised with radiolabelled mouse c-fos ( $2.1 \mathrm{~kb}$ fragment) or a reference house keeping gene, glyceraldehyde-3-phosphate dehydrogenase (GAPDH) cDNA probes (American Type Culture Collection, Rockville, MD, USA). ${ }^{27}$ Hybridisation signals were quantified by scanning laser densitometry using the Ultroscan XL enhanced laser densitometer (LKB, Bromma, Sweden). Signals were normalised with respect to GAPDH mRNA values and expressed as relative optical density in stimulated cells versus controls.
Measurement of IL- 6 protein levels by ELISA

IL-6 protein levels in ASM cell-conditioned medium, after $24 \mathrm{~h}$ of stimulation, were determined using a solid-phase sandwich ELISA as described previously. ${ }^{28}$ The increase in IL-6 secretion was expressed as nanograms per millilitre, and data are shown as the fold increase in IL- 6 secretion relative to controls. The detection limit of the IL-6 ELISA method was $50 \mathrm{pg}$ of IL- $6 / \mathrm{ml}$. No correction for cell number variation was made because the cells were serum deprived 16-24 h after plating out, allowing insufficient time for proliferation.

\section{$\left[{ }^{3} \mathrm{H}\right]$-Thymidine incorporation assay}

Effects of the different cytokines on DNA biosynthesis was evaluated by incorporation of metbyl$\left[{ }^{3} \mathrm{H}\right]$-thymidine. Cells were transferred into 24-well plates at a seeding density of $3 \times 10^{4}$ cells/well. After 


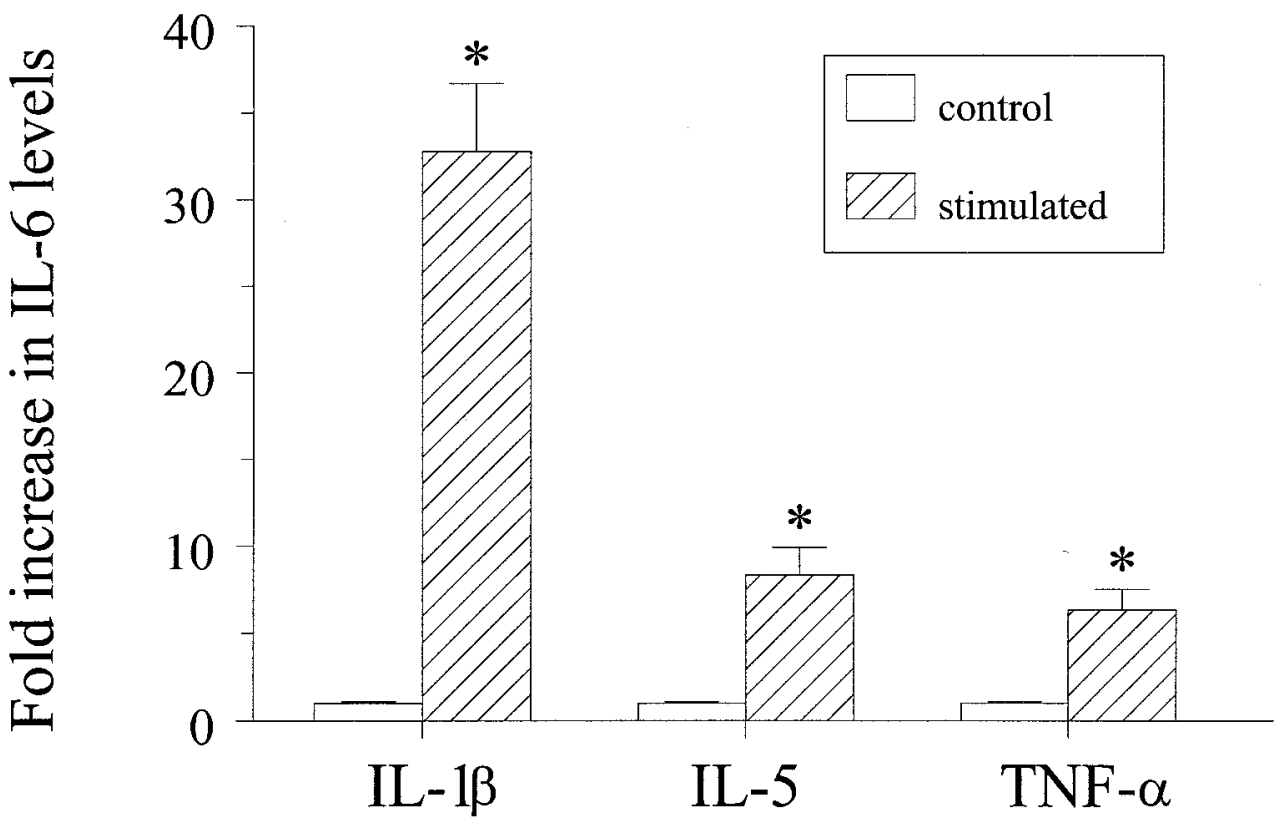

FIG. 2. Production and release of IL-6 by human airway smooth muscle (ASM) cells. Growth-arrested ASM cells were stimulated in the absence (control) or presence of different cytokines for $24 \mathrm{~h}$. Data represent the mean \pm SEM of triplicate values from three or four independent experiments using conditioned medium from ASM cells cultured from different patients. Data are expressed as the fold increase in IL-6 secretion compared with respective controls.

$24 \mathrm{~h}$ in culture, the sub-confluent cell monolayers were growth arrested as already described. Cells were incubated with $m e t h y l-\left[{ }^{3} \mathrm{H}\right]$-thymidine $(1 \mu \mathrm{Ci} /$ well $)$ in either fresh FBS-free DMEM (control), DMEM containing the various cytokines, or $10 \%$ serum for $1,2,3,4$ or 5 days. After stimulation, the cells were washed in PBS, fixed with ice-cold methanol and exposed to icecold trichloroacetic acid $(5 \% \mathrm{w} / \mathrm{v})$. The acid-insoluble fraction was lysed in $0.3 \mathrm{M} \mathrm{NaOH}$ and the incorporated radioactivity was determined in a liquid-scintillation counter (Packard 1500 Tri-carb liquid scintillation analyser; Packard-Becker BV, Delft, The Netherlands). The data are expressed as the fold increase in thymidine incorporation relative to controls.

\section{Cell counting}

To assess changes in cell number in relation to proinflammatory cytokines, we also performed direct cell counting. Cells were incubated with the aforementioned stimuli for 7 days. Following stimulation, the cell-conditioned medium was removed and the cells were washed twice in PBS and then detached in $50 \mu 1$ of trypsin/EDTA by incubating at room temperature for $10 \mathrm{~min}$. We then added $50 \mu 1 \mathrm{PBS}$ to each well and the cells were dispersed by gentle pipetting. The resulting cell suspension was added to $10 \mathrm{ml}$ of isotonic counting solution (sodium chloride, $6.38 \mathrm{~g} / \mathrm{l}$; sodium tetraborate, $0.2 \mathrm{~g} / 1$; boric acid, $1.0 \mathrm{~g} / 1$; EDTA $0.2 \mathrm{~g} / \mathrm{l}$ ) and the cells were counted in a CASY-1 Coulter counter (Schärfe system, Reutlingen, Germany).

\section{Statistical analysis}

All data in the figures and tables are presented as mean \pm SEM. Statistical analysis was performed using a two-tailed, independent sample $t$-test. Significance was accepted at $p<0.05$.

\section{Results}

\section{Expression of the c-fos proto-oncogene}

Expression of the proto-oncogene c-fos, a member of the leucine zipper family, was examined in cultured human ASM cells treated with different cytokines. Representative Northern blots showing the expression pattern of c-fos in relation to IL- $1 \beta$ $(0.5 \mathrm{ng} / \mathrm{ml})$, IL-5 $(2 \mathrm{ng} / \mathrm{ml})$, IL-6 $(5 \mathrm{ng} / \mathrm{ml})$ or TNF- $\alpha$ $(10 \mathrm{ng} / \mathrm{ml})$ are shown in Figure 1 . IL-1 $\beta$ and IL-5, IL6 and TNF- $\alpha$ induced the expression of mRNA encoding c-fos in cultured human ASM cells as early as $30 \mathrm{~min}$, and the expression levels reached a maximum between 45 and $60 \mathrm{~min}$. Rapidly and transiently induced mRNA levels declined abruptly to non-detectable levels at $120 \mathrm{~min}$, except in the case of IL-5 where c-fos mRNA levels remained elevated up to $120 \mathrm{~min}$ (Fig. 1B). To compare the expression pattern and to verify the integrity of total RNA samples, GAPDH, a housekeeping gene was used to re-hybridise the membranes. A strong dark band at $1.4 \mathrm{~kb}$ was expressed in each RNA preparation (Fig. 1 A-D). 


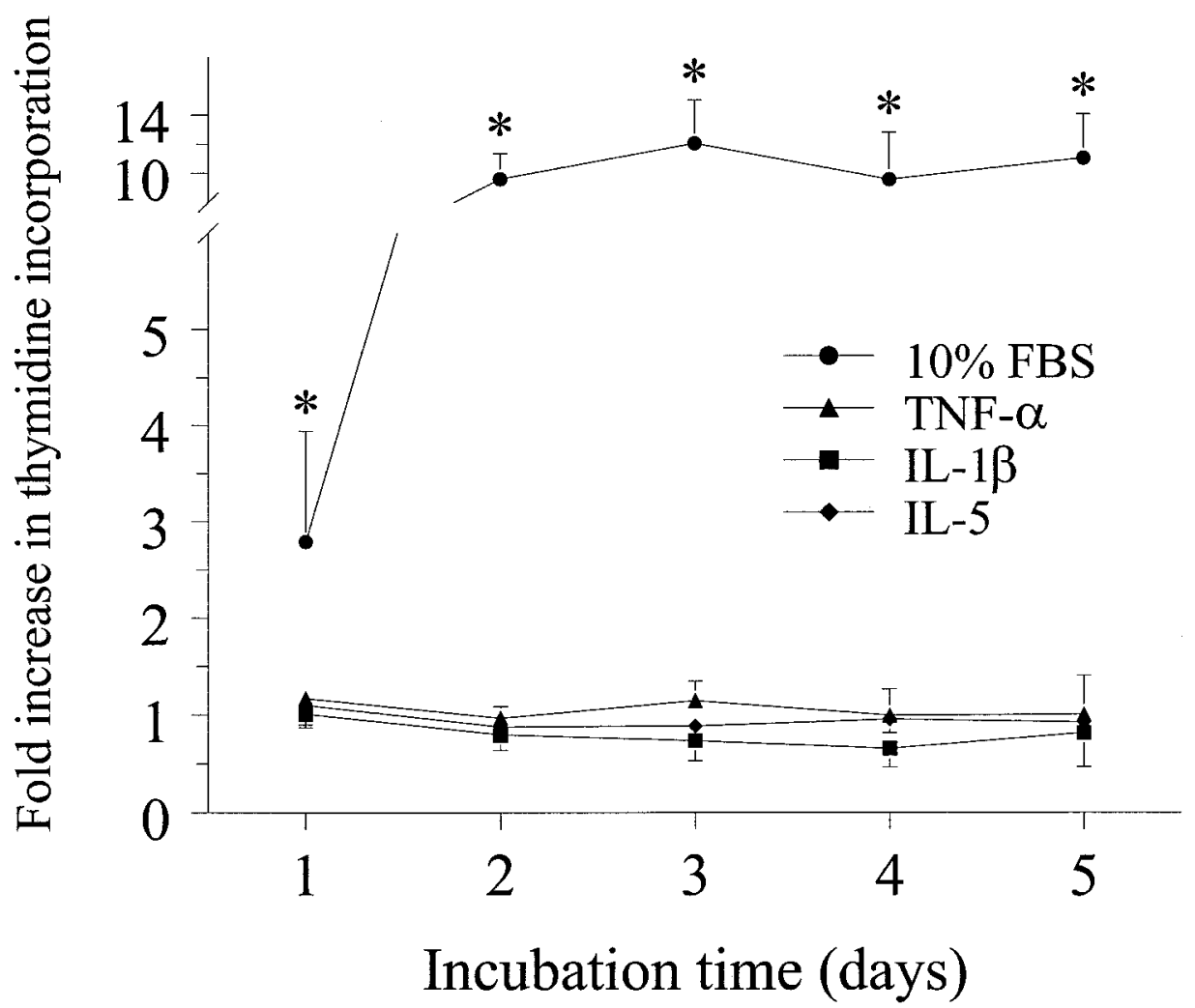

FIG. 3. Thymidine incorporation measured after 5 days in semi-confluent, growth arrested, human airway smooth muscle (ASM) cells stimulated with $10 \%$ serum (circles), $10 \mathrm{ng} / \mathrm{ml}$ TNF- $\alpha$ (triangles), $0.5 \mathrm{ng} / \mathrm{ml}$ IL- $1 \beta$ (squares) or $2 \mathrm{ng} / \mathrm{ml} \mathrm{IL}-5$ (diamonds). Values are calculated from three or four independent experiments of four determinations each, and expressed as the fold increase in thymidine incorporation relative to controls. FBS, foetal bovine serum.

\section{Release of IL-6 protein into the conditioned medium}

The concentration of IL-6 in the conditioned medium of cultured human ASM cells following $24 \mathrm{~h}$ of stimulation with IL-1 $\beta$, IL-5 and TNF- $\alpha$ was $6.56 \pm$ $0.78,1.10 \pm 0.08$ and $3.17 \pm 0.64 \mathrm{ng} / \mathrm{ml}$, respectively. Conditioned medium derived from controls cells showed only a negligible amount $(0.14 \pm 0.02 \mathrm{ng} / \mathrm{ml})$ of IL- 6 . The fold increase in IL-6 concentration in relation to different cytokines after normalising with their respective controls is shown in Figure 2. IL-1 $\beta$ was the most potent cytokine for cultured human ASM cells in producing IL-6 protein, where the levels rose over 30-fold as compared with the respective control (Fig. 2). To verify that the measured amounts of IL-6 in the conditioned medium were due to the release of de novo synthesised IL-6, we also assessed the concentration of IL- 6 in the cell lysates of unstimulated human ASM cells. These IL- 6 levels were found to be negligible $(0.10 \pm 0.01 \mathrm{ng} / \mathrm{ml})$.

\section{$\left[{ }^{3} \mathrm{H}\right]$-Thymidine incorporation}

Figure 3 shows the DNA biosynthesis data assessed by $\left[{ }^{3} \mathrm{H}\right]$-thymidine incorporation into DNA during a period of 5 days. We found that 10\% FBS increased thymidine incorporation up to 10 -fold as compared with cells cultured in medium deprived of FBS (controls). Surprisingly, none of the cytokines studied here could result in the induction of DNA biosynthesis measured by $\left[{ }^{3} \mathrm{H}\right]$-thymidine incorporation assay in this cultured human ASM cell model. Even in the presence of the cyclo-oxygenase inhibitor indomethacin, the aforementioned cytokines failed to elicit a proliferative response in cultured human ASM cells even up to 3 days of stimulation (Table 1).

\section{Cell counting}

Cell counts did not change after 7 days of incubation of serum-deprived human ASM cells with the different cytokines (TNF- $\alpha$, IL-1 $\beta$, IL-5 and IL- 6 ) at the concentrations mentioned earlier. The cell counts data depicted in Table 2 once again verify the nonmitogenic response of the cytokines studied here, and this data is in agreement with the $\left[{ }^{3} \mathrm{H}\right]$-thymidine incorporation results.

\section{Discussion}

The purpose of the present study was to investigate the relative contributions of a number of proinflammatory cytokines, on responses of cultured 
Table 1. $\left[{ }^{3} \mathrm{H}\right]$-Thymidine incorporation into DNA, measured after 3 days in semi-confluent, growth-arrested human airway smooth muscle cells stimulated with TNF- $\alpha(10 \mathrm{ng} / \mathrm{ml}), \mathrm{IL}-1 \beta(0.5 \mathrm{ng} / \mathrm{ml}), \mathrm{IL}-5(2 \mathrm{ng} / \mathrm{ml})$ and IL-6 $(5 \mathrm{ng} / \mathrm{ml})$ in the presence or absence (control) of $1 \mu \mathrm{M}$ indomethacin

\begin{tabular}{lrrrr}
\hline Treatment & \multicolumn{1}{c}{ TNF- $\alpha$} & IL-1 $\beta$ & IL-5 & IL-6 \\
\hline$-1 \mu \mathrm{M}$ indomethacin & $1.0 \pm 0.11$ & $1.0 \pm 0.11$ & $1.0 \pm 0.11$ & $1.08 \pm 0.16$ \\
$+1 \mu \mathrm{M}$ indomethacin & $0.88 \pm 0.12$ & $1.08 \pm 0.20$ & $0.97 \pm 0.20$ & $0.88 \pm 0.12$ \\
\hline
\end{tabular}

Values are calculated from one to three independent experiments of four determinations each, and are expressed as the fold increase in thymidine incorporation relative to controls \pm SEM. Baseline thymidine incorporation at $72 \mathrm{~h}$ of stimulation was $5500 \pm 1000$ disintegration per minute $(\mathrm{dpm}) /$ well.

human ASM cells, by evaluating their individual ability to induce the expression of the immediate early response gene c-fos, as well as the release of the pleiotropic cytokine IL- 6 . Also, the ability of the proinflammatory cytokines to induce cell mitogenesis, under identical experimental conditions, was evaluated. Our results demonstrate that a rapid and transient expression of mRNA encoding c-fos was induced by all of the cytokines investigated. However, none of the cytokines induced DNA biosynthesis or an increase in cell numbers in this human ASM cell model. Moreover, all of the cytokines investigated induced the release of de novo synthesised IL-6 protein into the cell-conditioned medium.

The rapid and transient induction of the immediate early response gene c-fos, and subsequent cell proliferation and/or differentiation, has previously suggested that c-fos can be considered a proliferation marker in ASM cells. ${ }^{16,30}$ However, it has also been shown that c-fos induction alone is insufficient for cell proliferation in a number of cells of mesenchymal origin. ${ }^{31,32}$ Histamine and ET-1 have previously been shown to increase levels of c-fos mRNA, peaking at $30 \mathrm{~min}$ of stimulation, in canine and ovine ASM cells, respectively. ${ }^{16,30}$ Both of these studies associated c-fos expression with ASM cell mitogenesis. However, we could not demonstrate that c-fos expression was directly associated with a proliferative response in our human ASM cell model. These findings are also supported by one of our previous studies, where we showed that angiotensin II induced the expression of c-fos without subsequent cell proliferation. ${ }^{27}$

Table 2. Human airway smooth muscle cell numbers after 7 days of stimulation with different cytokines

Treatment

Cell number

(fold increase relative to control)

\begin{tabular}{ll}
\hline TNF- $\alpha$ & $0.97 \pm 0.10$ \\
IL-1 $\beta$ & $0.77 \pm 0.12$ \\
IL-5 & $1.30 \pm 0.39$ \\
IL-6 & $1.06 \pm 0.13$
\end{tabular}

Values are calculated from three or four independent experiments of four determinations each, and are expressed as the fold increase in cell number relative to controls \pm SEM.
Stimulation of human ASM cells with either TNF- $\alpha$ $(10 \mathrm{ng} / \mathrm{ml})$ or $\mathrm{IL}-1 \beta \quad(0.5 \mathrm{ng} / \mathrm{ml})$, in serum-free medium, induced the expression of c-fos but did not result in an increase in thymidine incorporation or cell counts in our study. Although work from other groups has previously shown a mitogenic response, it is important to emphasise that the culture media,TNF$\alpha(10 \mathrm{ng} / \mathrm{ml})$ in the study from Amrani et al. ${ }^{14}$ and IL$1 \beta(0.1 \mathrm{ng} / \mathrm{ml})$ in the study from De et al. ${ }^{13}$ contained serum. ${ }^{12-14}$ TNF- $\alpha$, IL-1 $\beta$ and growth factors (present in serum) can activate mitogen-activated protein (MAP) kinases in smooth muscle cells. ${ }^{33-35}$ MAP kinases are key transducers of extracellular signals in pathways leading to cell proliferation and differentiation. Signals activated by TNF- $\alpha$ or IL-1 $\beta$ together with serum may synergistically induce proliferation, possibly explaining the previously reported proliferative response. Stewart $e t a l$. found an increase in thymidine incorporation using TNF- $\alpha$ at very low concentrations $(5.0 \mathrm{pg} / \mathrm{ml}$ to $0.5 \mathrm{ng} / \mathrm{ml})$ in human ASM cells, but at higher concentrations $(5.0 \mathrm{ng} / \mathrm{ml})$ this effect was abolished. ${ }^{12}$ De et al. also found that IL1 in the absence of indomethacin inhibited proliferation of ASM cells. ${ }^{13}$ We did not observe proliferative effects in either the absence or in the presence of indomethacin, again suggesting that considerably low concentrations of serum-derived factors may synergistically contribute to ASM cell mitogenesis.

The upregulation of c-fos expression, in human ASM cells, by the pro-inflammatory cytokines investigated in our study, was thus insufficient for the induction of cell proliferation. Radiolabelled thymidine incorporation demonstrated that serum-induced DNA biosynthesis in cultured human ASM cells, which is a well-established phenomenon in ASM cell culture. IL-5 stimulation of human ASM cell proliferation has not previously been reported, although ASM cells have been reported to express and secrete IL-5 in response to the serum obtained from allergic asthma patients. ${ }^{36}$ We found that IL-5 $(2 \mathrm{ng} / \mathrm{ml})$ is not mitogenic for human ASM cells, even in the presence of indomethacin.

The c-fos protein, which is able to translocate to the nucleus and bind to c-jun, forms a heterodimeric complex known as activator protein-1 (AP-1). This transcription factor can activate gene transcription by 
binding to the AP-1 site in the promoter region of target genes. Several recent studies have shown that ASM cell stimulation by cytokines leads to the expression and subsequent release of a number of inflammatory cytokines and chemokines. ${ }^{28,37-42}$ The majority of these pro-inflammatory cytokines contain AP-1 binding sites in the promoter region of their genes. We have recently shown that c-fos induction precedes IL- 6 protein secretion by human ASM cells. ${ }^{28}$ The transient upregulation of c-fos that we measured in this study may contribute to the induction and release of cytokines, such as IL-6, thereby playing a role in the regulation of inflammatory responses in asthmatic airways. IL- 6 is upregulated in the bronchoalveolar lavage fluid from symptomatic asthma patients and has pro-inflammatory effects that may be relevant to airway wall inflammation. These include mucus hypersecretion, the terminal differentiation of $B$ cells into antibody producing cells, upregulation of IL-4-dependent IgE production, and differentiation of immature mast cells. ${ }^{15-18}$

The present study suggests that ASM cells may play a role in the regulation of airway inflammation through the production of cytokines, like IL- 6 . This may occur via upregulation of different genes, including cytokines and chemokines such as TGF- $\beta_{1}$, IL-8, granulocyte macrophage-colony stimulating factor or RANTES. ${ }^{27,28,37-39}$ Although the individual cytokines investigated in our study did not induce human ASM cell proliferation, we cannot exclude that their concerted actions in asthmatic airways may contribute to ASM remodelling. Evidence for the importance of combinations of mediators has recently been published. ${ }^{43}$ Whether the endogenous generation of cytokines by ASM cells, and especially the release of IL-6, contributes to the pathogenesis of airway inflammation and remodelling is unclear, but the capacity of ASM cells to produce IL-6 suggests that these cells could participate in local inflammatory events in the airways.

ACKNOWLEDGEMENTS. The authors are grateful to Dr Rolf Müller for generously providing the c-fos cDNA probe. This study was supported by The Netherlands Asthma Foundation, grant number NAF 95.46.

\section{References}

1. Ebina M, Takahashi T, Chiba T, Motomiya M. Cellular hypertrophy and hyperplasia of airway smooth muscles underlying bronchial asthma. A 3-D morphometric study. Am Rev Respir Dis 1993; 148: 720-726.

2. Heard BE, Hossain S. Hyperplasia of bronchial muscle in asthma.J Pathol 1973; 110: 310-331.

3. Jeffery PK. Morphology of the airway wall in asthma and in chronic obstructive pulmonary disease. Am Rev Respir Dis 1991; 143 1152-1158.

4. Borish L, Mascali JJ, Dishuck J, Beam WR, Martin RJ, Rosenwasser LJ Detection of alveolar macrophage-derived IL-1 beta in asthma. Inhibition with corticosteroids. I Immunol 1992; 149: 3078-3082.

5. Broide DH, Lotz M, Cuomo AJ, Coburn DA, Federman EC, Wasserman SI. Cytokines in symptomatic asthma airways. J Allergy Clin Immunol 1992; 89: $958-967$.

6. Lechin F, van der Dijs B, Orozco B, Lechin M, Lechin AE. Increased levels of free serotonin in plasma of symptomatic asthmatic patients. Ann Allergy Asthma Immunol 1996; 77: 245-253.
7. Liu MC, Bleecker ER, Lichtenstein LM, et al. Evidence for elevated levels of histamine, prostaglandin D2, and other bronchoconstricting prostaglandins in the airways of subjects with mild asthma. Am Rev Respir Dis 1990; 142: 126-132.

8. Mitsunobu F, Mifune T, Hosaki Y, et al. Different roles of histamine and leukotriene $\mathrm{C} 4$ in the airways between patients with atopic and nonatopic asthma. J Asthma 1998; 35: 367-372.

9. Redington AE, Springall DR, Ghatei MA, et al. Endothelin in bronchoalveolar lavage fluid and its relation to airflow obstruction in asthma. $\mathrm{Am}$ J Respir Crit Care Med 1995; 151: 1034-1039.

10. Suter PM, Suter S, Girardin E, Roux-Lombard P, Grau GE, Dayer JM. High bronchoalveolar levels of tumor necrosis factor and its inhibitors, interleukin-1, interferon, and elastase, in patients with adult respiratory distress syndrome after trauma, shock, or sepsis. Am Rev Respir Dis 1992; 145: 1016-1022

11. Teran LM, Carroll MP, Shute JK, Holgate ST. Interleukin 5 release into asthmatic airways 4 and 24 hours after endobronchial allergen challenge: its relationship with eosinophil recruitment. Cytokine 1999; 11: 518-522.

12. Stewart AG, Tomlinson PR, Fernandes DJ, Wilson JW, Harris T. Tumor necrosis factor alpha modulates mitogenic responses of human cultured airway smooth muscle. Am J Respir Cell Mol Biol 1995; 12: 110-119.

13. De S, Zelazny ET, Souhrada JF, Souhrada M. IL-1 beta and IL-6 induce hyperplasia and hypertrophy of cultured guinea pig airway smooth muscle cells. J Appl Physiol 1995; 78: 1555-1563.

14. Amrani Y, Panettieri RA Jr, Frossard N, Bronner C. Activation of the TNF alpha-p 55 receptor induces myocyte proliferation and modulates agonistevoked calcium transients in cultured human tracheal smooth muscle cells. Am J Respir Cell Mol Biol 1996; 15: 55-63.

15. Martin LD, Rochelle LG, Fischer BM, Krunkosky TM, Adler KB. Airway epithelium as an effector of inflammation: molecular regulation of secondary mediators. Eur Respir J 1997; 10: 2139-2146.

16. Muraguchi A, Hirano $\mathrm{T}$, Tang $\mathrm{B}$, et al. The essential role of $\mathrm{B}$ cell stimulatory factor 2 (BSF-2/IL-6) for the terminal differentiation of B cells. J Exp Med 1988; 167: 332-344.

17. Sanchez-Guerrero IM, Herrero N, Muro M, et al. Co-stimulation of cultured peripheral blood mononuclear cells from intrinsic asthmatics with exogenous recombinant IL-6 produce high levels of IL-4-dependent IgE. Eur Respir J 1997; 10: 2091-2096.

18. Pompen M, Smids BS, Dingemans KP, Jansen HM, Out TA, Lutter R. Lung epithelial H292 cells induce differentiation of immature HMC-1 mast cells by interleukin-6 and stem cells factor. Clin Exp Allergy 2000; 30: 1104-1112.

19. Shanley TP, Foreback JL, Remick DG, Ulich TR, Kunkel SL, Ward PA. Regulatory effects of interleukin-6 in immunoglobulin $G$ immunecomplex-induced lung injury. Am J Pathol 1997; 151: 193-203.

20. Xing Z, Gauldie J, Cox G, et al. IL-6 is an antiinflammatory cytokine required for controlling local or systemic acute inflammatory responses. J Clin Invest 1998; 101: 311-320.

21. Zitnik RJ, Elias JA. Interleukin-6 in the lung. In: Lenfant CEE, eds. Lung Biology in Health and Disease. New York: Dekker, 1993:229-280.

22. Tilg H, Trehu E, Atkins MB, Dinarello CA, Mier JW. Interleukin-6 (IL-6) as an anti-inflammatory cytokine: induction of circulating IL-1 receptor antagonist and soluble tumor necrosis factor receptor p55. Blood 1994; 83: $113-118$.

23. DiCosmo BF, Geba GP, Picarella D, et al. Airway epithelial cell expression of interleukin-6 in transgenic mice. Uncoupling of airway inflammation and bronchial hyperreactivity. J Clin Invest 1994; 94: 2028-2035.

24. Wang J, Homer RJ, Chen Q, Elias JA. Endogenous and exogenous IL-6 inhibit aeroallergen-induced Th2 inflammation. J Immunol 2000; 165 : 4051-4061.

25. Karin M, Liu Z, Zandi E. AP-1 function and regulation. Curr Opin Cell Biol 1997; 9: 240-246.

26. Panettieri RA, Yadvish PA, Kelly AM, Rubinstein NA, Kotlikoff MI Histamine stimulates proliferation of airway smooth muscle and induces c-fos expression. Am J Physiol 1990; 259: L365-L371.

27. McKay S, de Jongste JC, Saxena PR, Sharma HS. Angiotensin II induces hypertrophy of human airway smooth muscle cells: expression of transcription factors and transforming growth factor-beta1. Am J Respir Cell Mol Biol 1998; 18: 823-833.

28. McKay S, Hirst SJ, Haas MB, et al. Tumor necrosis factor-alpha enhances mRNA expression and secretion of interleukin-6 in cultured human airway smooth muscle cells. Am J Respir Cell Mol Biol 2000; 23: 103-111.

29. Johnson PRA, Armour CL, Carey D, Black JL. Heparin and PGE-2 inhibit DNA synthesis in human airway smooth muscle cells in culture. Am J Physiol 1995; 269: 514-519.

30. Glassberg MK, Ergul A, Wanner A, Puett D. Endothelin-1 promotes mitogenesis in airway smooth muscle cells. Am J Respir Cell Mol Biol 1994; 10: 316-321.

31. Sachinidis A, Schulte K, Ko Y, et al. The induction of early response genes in rat smooth muscle cells by PDGF-AA is not sufficient to stimulate DNAsynthesis. FEBS Lett 1993; 319: 221-224.

32. Paulsson Y, Bywater M, Heldin CH, Westermark B. Effects of epidermal growth factor and platelet-derived growth factor on c-fos and c-myc mRNA levels in normal human fibroblasts. Exp Cell Res 1987; 171: 186-194. 
33. Laporte JD, Moore PE, Lahiri T, Schwartzman IN, Panettieri RA Jr, Shore SA. p38 MAP kinase regulates IL-1 beta responses in cultured airway smooth muscle cells. Am J Physiol Lung Cell Mol Physiol 2000; 279: L932-L941.

34. Hedges JC, Singer CA, Gerthoffer WT. Mitogen-activated protein kinases regulate cytokine gene expression in human airway myocytes. $\mathrm{Am} \mathrm{J}$ Respir Cell Mol Biol 2000; 23: 86-94.

35. Jiang B, Brecher P. $N$-Acetyl-ı-cysteine potentiates interleukin-1beta induction of nitric oxide synthase: role of p44/42 mitogen-activated protein kinases. Hypertension 2000; 35: 914-918.

36. Hakonarson H, Maskeri N, Carter C, Grunstein MM. Regulation of Th1and Th2-type cytokine expression and action in atopic asthmatic sensitized airway smooth muscle. J Clin Invest 1999; 103: 1077-1087.

37. Hallsworth M. Cultured human airway smooth muscle cells stimulated by IL-1beta enhance eosinophil survival. Am J Respir Cell Mol Biol 1998; 19: $910-919$.

38. John M, Hirst SJ, Jose PJ, et al. Human airway smooth muscle cells express and release RANTES in response to $\mathrm{T}$ helper 1 cytokines: regulation by T helper 2 cytokines and corticosteroids. J Immunol 1997; 158: 1841-1847.

39. John M, Au BT, Jose PJ, et al. Expression and release of interleukin-8 by human airway smooth muscle cells: inhibition by Th- 2 cytokines and corticosteroids. Am J Respir Cell Mol Biol 1998; 18: 84-90.

40. McKay S, De Jongste JC, Hoogsteden HC, Saxena PR, Sharma HS. Interleukin-1b induced expression of transcription factors precedes upregulation of interleukin-6 in cultured human airway smooth muscle cells [abstract]. Eur Respir J 1999; 12: 57s.

41. Pype JL, Dupont LJ, Menten P, et al. Expression of monocyte chemotactic protein (MCP)-1, MCP-2, and MCP-3 by human airway smooth-muscle cells. Modulation by corticosteroids and T-helper 2 cytokines. $A m \mathrm{~J}$ Respir Cell Mol Biol 1999; 21: 528-536.

42. Ghaffar O, Hamid Q, Renzi PM, et al. Constitutive and cytokinestimulated expression of eotaxin by human airway smooth muscle cells. Am J Respir Crit Care Med 1999; 159: 1933-1942.

43. Ediger TL, Toews ML. Synergistic stimulation of airway smooth muscle cell mitogenesis. J Pharmacol Exp Ther 2000; 294: 1076-1082.

\section{Received 12 April 2001;}

accepted 23 april 2001 


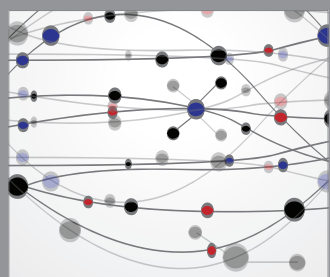

The Scientific World Journal
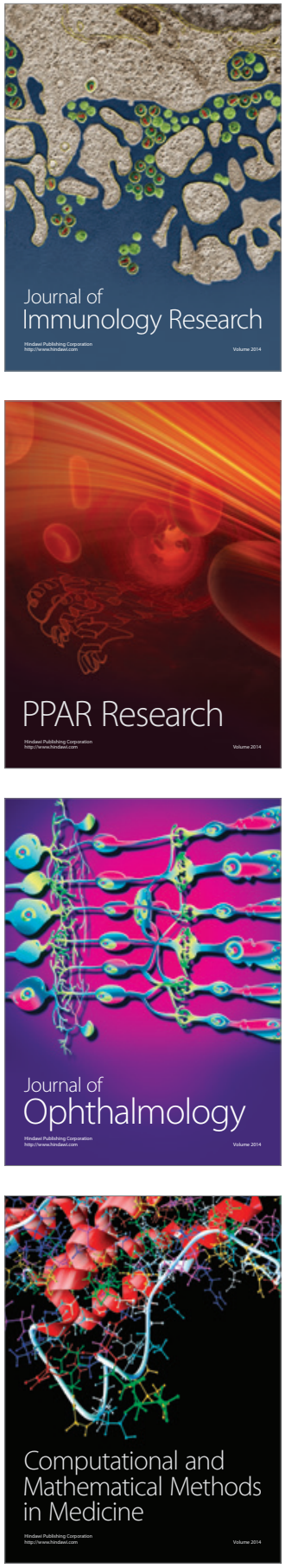

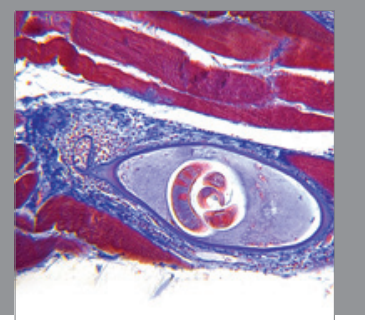

Gastroenterology

Research and Practice
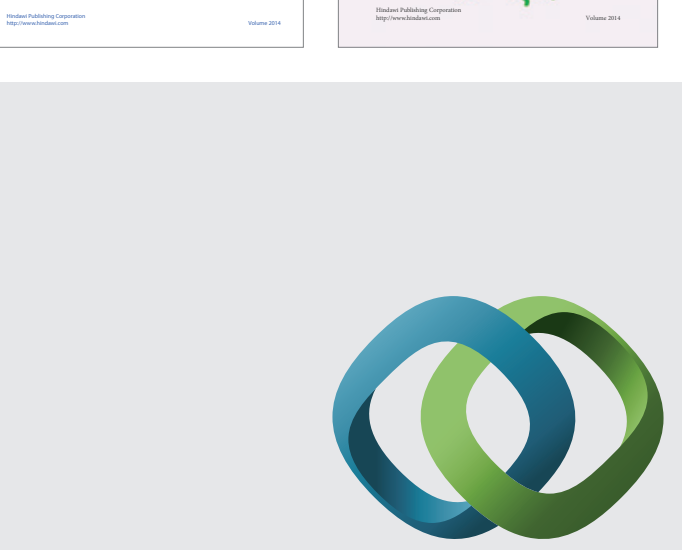

\section{Hindawi}

Submit your manuscripts at

http://www.hindawi.com
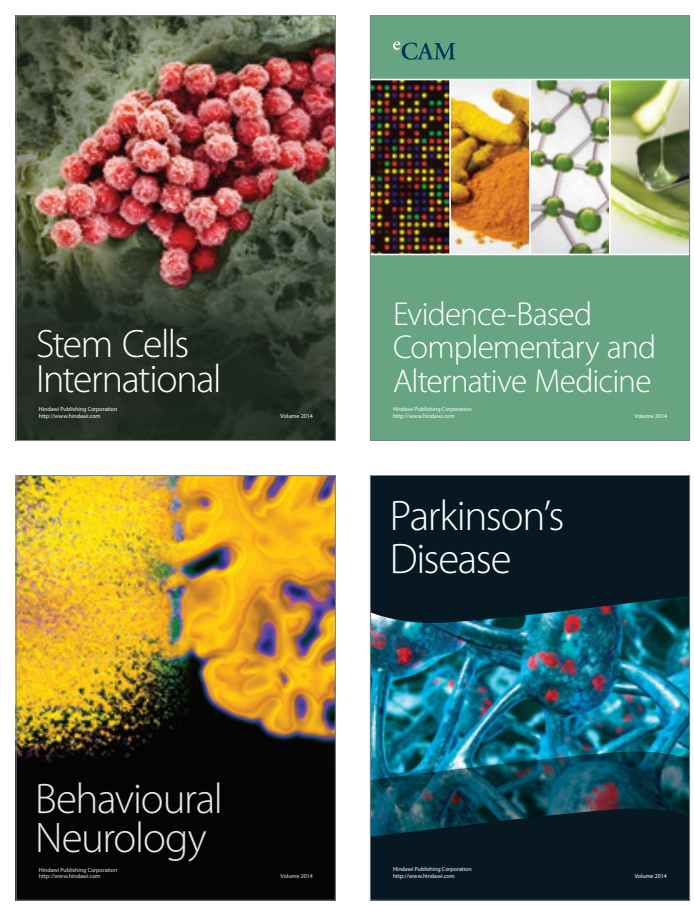

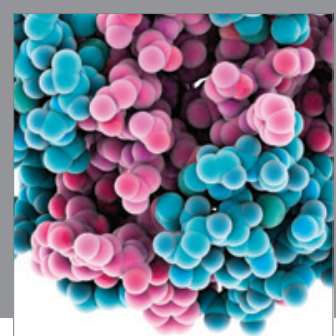

Journal of
Diabetes Research

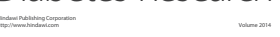

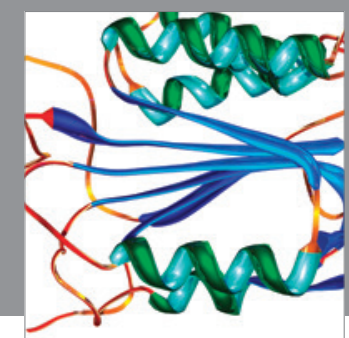

Disease Markers
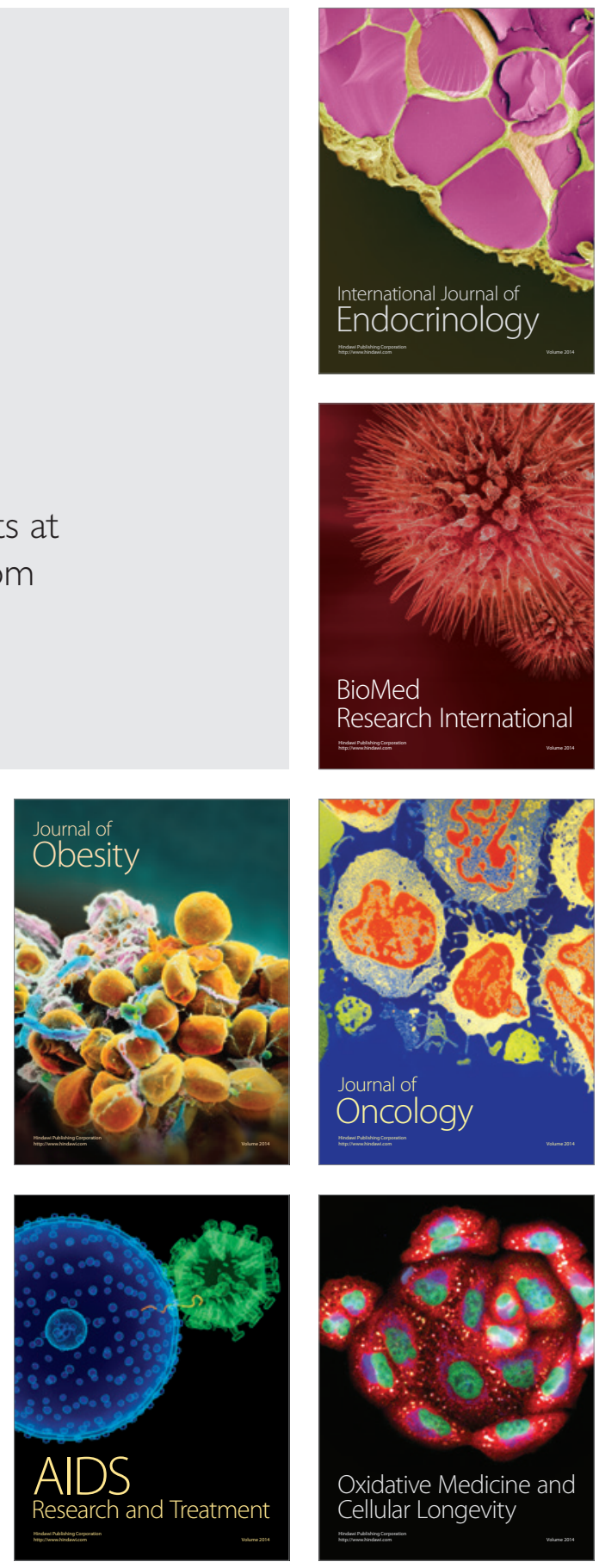